\title{
Blurring Public and Private Security in Indonesia: Corporate Interests and Human Rights in a Fragile Environment
}

\author{
Nigel D. White ${ }^{1} \cdot$ Mary E. Footer $^{1} \cdot$ Kerry Senior $^{2} \cdot$ Mark van Dorp $^{3}$. \\ Vincent Kiezebrink ${ }^{3}$. Y. Wasi Gede Puraka ${ }^{4}$. Ayudya Fajri Anzas ${ }^{4}$
}

Published online: 21 August 2018

(c) The Author(s) 2018

\begin{abstract}
While legal and policy frameworks are based on a clear distinction between public and private security actors and functions, the reality on the ground in Indonesia reveals that there is a high level of corporate capture of public security services, including the military and police, who often operate alongside private security companies (mainly local, though there is some evidence of an emerging international presence), and the security personnel of companies engaged in the natural resources industry. This has led to serious human rights violations of indigenous peoples and other local inhabitants, who often find themselves entangled in protracted conflicts with multinational companies over access to their land. Two case studies involving fieldwork in the logging and palm oil sectors in Sumatra reveal a pernicious and deliberate erosion and violation of rights of local inhabitants across the spectrum of security actors, showing that public security actors are protecting corporate interests rather than performing public functions. The implications of these findings are considered in terms of legal responsibilities as well as access to justice. The article reasons towards what are argued to be necessary legal and policy changes.
\end{abstract}

Keywords Accountability - Corporate capture - Corporate-community conflict . Human rights · Indonesia $\cdot$ Land rights $\cdot$ Logging $\cdot$ Private military and security companies · Natural resources industry $\cdot$ Palm oil $\cdot$ Public-private security · Responsibility

\footnotetext{
The research that led to this article was funded by The Netherlands Organization for Scientific Research (NWO/WOTRO) as part of the Knowledge Platform Security and Rule of Law, under the call for applied research on the influence of transnational challenges in Fragile and Conflict-Affected Settings (Project Code W 08.400.145), 10 June 2016-10 February 2017.
}

Nigel D. White

nigel.white@nottingham.ac.uk

Extended author information available on the last page of the article 


\section{Introduction}

There have been widespread human rights violations across the Indonesian archipelago by the Indonesian security sector working for or on behalf of multinational corporations (MNCs) in the commodities sector. Media, NGO and IGO reports, referred to in the course of this article, point to a range of human rights violations such as land grabbing, forcible eviction, denial of customary land rights, murder, torture, sexual violence, assault, intimidation, arbitrary arrest and illegal detention. These human rights violations have been perpetrated by members of the Indonesian National Armed Forces [Tentara Nasional Indonesia (TNI)], members of the Indonesian National Police [Kepolisian Negara Republik Indonesia (Polri)], especially the Mobile Brigade Corps [Korps Brigade Mobil (Brimob)], as well as local private security guards and militia, often directly linked to the MNCs involved. Successive government policy on land and natural resources has exacerbated the problem combined with the influence of the military and its links to the business sector, both of which have made matters more complex.

Military involvement in the economic and political life of the country is intertwined with the history of the country since its independence, especially the New Order administration (1966-1998), when the military were rewarded with political and business opportunities for supporting President Suharto's economic development policies. ${ }^{1}$ Suharto cultivated relationships with MNCs for the commercial exploitation of natural resources while the military and police seized lands from local communities using violence and intimidation. ${ }^{2}$ Payments were made to the military and police for security services to MNCs, including the high profile companies Exxon Mobil and Freeport-McMoRan. ${ }^{3}$ Despite reforms in the reformasi era following the fall of Suharto in the aftermath of Asian Financial Crisis (1997-1998), ${ }^{4}$ the military and police continued to provide security to MNCs up to the present day with little regard for the human rights of local communities under government land policy. ${ }^{5}$ Democratic reforms have mainly addressed the military's political role with limited reform of its business interests and commercial security practices. ${ }^{6}$ Increasing tension between the police and military, as a result of government reforms to try and separate state security actors from their business interests, have contributed to rising instability in the region and the emergence of private security actors. ${ }^{7}$

The aim of this article is to explore the relationships between security actors and businesses especially in the natural resources sector in Indonesia within the normative framework provided by international law and processes. Rather than a straightforward application of law to the facts, complex and disputed as they are,

\footnotetext{
1 Crouch (1979), p. 577.

2 Human Rights Watch (2003), pp. 12-14, 33-34.

3 Human Rights Watch (2006), pp. 45-56, 133; Down to Earth (2001); Global Witness (2005); Yunanto (2006), p. 51; Clarke (2008), p. 9.

4 Heiduk (2014), p. 304.

5 Human Rights Watch (2010), pp. 3-6.

6 Ibid., pp. 8-13; Kingsbury (2012), p. 11; Nani (2015).

7 Human Rights Watch (2006), pp. 66-70; Liss (2014), chapter 7; Sciascia (2013), p. 178.
} 
the article proceeds from a critical basis about the inability of international law and institutions to provide a workable framework for the regulation of both public and private security actors within a developing state where authority and sovereignty, and the line between what is public and private, are difficult to locate. The article unearths the reasons behind this failure of international law, to identify the extent of abuse of individuals within communities affected by natural resources exploitation and the impunity of security actors for such abuse, and provides suggestions for the improved traction of law and increased accountability of security actors.

As well as doctrinal legal analysis exposing the difficulties in application of the various international legal regimes, centred on international human rights law, the study combines documented human rights abuse at the hands of security actors with two case studies on palm oil and logging in specific areas of Indonesia. The case studies were undertaken to unearth the day-to-day reality of communities living with large scale natural resources exploitation, and to illustrate the levels of accountability for infractions of their rights. Qualitative techniques were used in the fieldwork, whereby the main corpus of data was gained by conducting in-depth interviews with the stakeholders on experiences, practices and perspectives on company security. Aside from in-depth interviews, focus group discussions were also used as data collection techniques in order to obtain a fuller picture through the involvement of various resource persons. The data collection process was guided by questions concerning business practices, human rights, and social and environmental impacts. The guiding questions were designed before the research team visited the field and were further developed throughout the research process. A snow ball sampling method was used for the process of collecting data and finding relevant resource persons, in order to build trust among the interviewed resource persons and because the issues related to security were considered to be sensitive. As a consequence, the research had to rely on the role of gatekeepers who could facilitate the meetings between researchers and resource persons.

In terms of the structure of the article, Sect. 2 establishes the principal applicable international legal framework within which the actions of security actors can be judged-international human rights law-to show that Indonesia has obligations, and also that human rights bodies have repeatedly criticised the behaviour of Indonesian security forces, but have failed to fully understand the nature of security in that country. Section 3 explores the difficulties in establishing the responsibility of the Indonesian state for human rights abuses due to the blurring of public and private security in Indonesia, while Sect. 4 deepens this analysis though the lens of 'state capture' whereby powerful interest groups from the military and business have seized the regulatory agenda for their own ends. The efforts of the international community to reign in the activities of private security actors are shown in Sect. 5 to be inadequate in the case of Indonesia as they are clearly focused on the Western model of outsourcing and not on the endemic blurring of public and private actors in developing countries such as Indonesia. Section 6 then explores in greater depth the relationship between business and security in Indonesia and the national laws that govern it, and engages with some of the softer forms of international regulation, which seem better designed to tackle the reality of the intertwined nature of the relationship, but ultimately are shown to fall short of this. This is driven home 
in Sect. 7 which presents clear evidence of persistent, pernicious and largely unpunished human rights abuse of villagers and communities by a combination of military, police and private security actors all working in one way or another for businesses engaged in the natural resources sector. This is done through collecting evidence from publicly available sources and then in Sects. 8 and 9 through the case studies on palm oil and logging mentioned above. These sectors and case studies best illustrate the abuse that occurs at the source of production, away from the eyes of the media and civil society, involving communities who are isolated and struggling to survive within areas occupied by palm oil and timber producers. Evidence of legal responsibility of any sort - governmental, corporate or individual-for such abuse is exposed in Sect. 10, which shows the limited accountability of security actors who have committed serious abuses and the lack of access to justice for victims of such abuse. Section 11 concludes the article with a summary of the findings and recommendations for the future.

\section{Indonesia, Human Rights and Security}

In terms of human rights compliance by Indonesia, there is certainly an upward trend in ratification of the key treaties, namely the International Convention on the Elimination of all Racial Discrimination 1966 (Indonesia became a party in 1999); the International Covenant on Civil and Political Rights (ICCPR) 1966 (party in 2006), the International Covenant on Economic, Social and Cultural Rights (ICESCR) 1966 (party in 2006), the Convention on the Elimination of All Forms of Discrimination against Women (CEDAW) 1979 (party in 1984); the Convention against Torture and Other Cruel, Inhuman or Degrading Treatment or Punishment (CAT) 1984 (party in 1998); Convention on the Rights of the Child 1989 (party in 1990); International Convention on the Protection of the Rights of All Migrant Workers and Members of their Families 1990 (party in 2012); and the Convention of the Rights of Persons with Disabilities 2006 (party in 2011).

In the main, its reservations and declarations to these treaties have been concerned with dispute resolution and self-determination and are designed to protect the territorial integrity of the whole of Indonesia. ${ }^{8}$ However, Indonesia has not accepted any individual complaints mechanisms that may be attached or included in any of the above treaties, meaning that individuals who allege human rights abuse do not have any direct access to international human rights bodies. ${ }^{9}$ This is clearly more effective for Indonesia in restricting international-level accountability for violations than any reservation to the main treaties. Neighbouring Philippines, for example, is a country that has accepted the individual complaints mechanisms under both the

\footnotetext{
${ }^{8}$ See recommendations in Report of the Working Group on the Universal Periodic Review: Indonesia, UN Doc. A/HRC/21/7 (5 July 2012), adopted by the Human Rights Council in Decision 21/105 (19 September 2012).

9 While Indonesia has not declared its acceptance of the individual complaints mechanisms under Art. 22 CAT 1984, it did accept the inquiry procedure under Art. 20 in 1998. Indonesia has signed the optional protocol to CEDAW in 2000 but has not ratified it.
} 
ICCPR in 1989 and CEDAW in 2003, and has been the subject of complaints that not only highlight the human rights record of the government but put pressure on it to improve and reform its protection of human rights.

As regards a review of Indonesia's record by treaty-based human rights bodies, the fact that Indonesia has only ratified the main human rights treaties relatively recently (ICCPR and ICESCR in 2006), has meant that it has gone through a limited number of reporting rounds. This provides for some degree of accountability, but a review of these reports with particular focus on the Committees' criticism of Indonesia's public and private security forces and the role of private businesses in Indonesia, shows that it is quite limited. The reporting process is an iterative one but the baseline reports should at least address fundamental problems such as the provision of security by a state, arguably its raison d'être, and ensuring that state security actors do not violate citizens' rights - a basic negative obligation; and the prevention of human rights abuse by private actors - a basic positive obligation.

An overview of reports on Indonesia by the various treaty Committees shows significant concern and condemnation of the actions of Indonesian security forces and other issues relevant to this study. In 2002, the Committee against Torture welcomed the 'formal separation of the police from the military in 1999, as a vital aspect of the effort to ensure an independent civilian authority responsible for maintaining law and order'. ${ }^{10}$ Nonetheless, it was concerned about: 'the large number of allegations of acts of torture and ill-treatment committed by members of the police forces, especially the mobile police units ("Brimob"), the army (TNI), and paramilitary groups reportedly linked to authorities, and in areas of armed conflict (Aceh, Papua, Maluku, etc.)'; 'allegations that paramilitary groups, reported to be perpetrators of torture and ill-treatment in Indonesia, are supported by some parts of the military, and sometimes reportedly are joined by military personnel'; and 'allegations that human rights abuses related to the Convention are sometimes committed by military personnel employed by businesses in Indonesia to protect their premises and to avoid labour disputes'. ${ }^{11}$

In 2008, the Committee against Torture expressed deep concern 'about numerous, ongoing credible and consistent allegations, corroborated by the report of the Special Rapporteur on torture and other sources, of the routine and disproportionate use of force and widespread torture and other cruel, inhuman and degrading treatment or punishment by members of the security and police forces, including by members of the armed forces, mobile police units ("Brimob") and paramilitary groups during military and "sweep" operations, especially in Papua, Aceh and in other provinces where there have been armed conflicts'. ${ }^{12}$

The Committee on the Elimination of Racial Discrimination reported in 2007 concern 'about the plan to establish oil palm plantations over some $850 \mathrm{~km}$ along the Indonesia-Malaysia border in Kalimantan as part of the Kalimantan Border Oil Palm Mega-project, and the threat this constitutes to the rights of indigenous peoples

${ }^{10}$ UN Doc. A/57/44 (2002), para. 41.

11 Ibid., para. 42.

12 UN Doc. CAT/C/IDN/CO/2 (2 July 2008), para. 11. 
to own their lands and enjoy their culture'. It noted with deep concern 'reports according to which a high number of conflicts arise each year throughout Indonesia between local communities and palm oil companies' ${ }^{13}$

In 2012 the Committee on the Elimination of Discrimination against Women expressed deep concern 'that sexual violence, especially rape, has reportedly been a recurring form of violence against women during conflict, including the events of 1965, the 1974-1999 conflict in the then East Timor Province, the May 1998 riots, the conflict in Aceh Province, the deployment of security and defence forces in Maluku Province and Poso (Central Sulawesi Province) and the conflicts in East Java and Papua Provinces'. ${ }^{14}$

In 2013 the Human Rights Committee expressed concern 'at increased reports of excessive use of force and extrajudicial killings by the police and the military during protests, particularly in West Papua, Bima and West Nusa Tenggara. The Committee was particularly concerned at reports that the State party uses its security apparatus to punish political dissidents and human rights defenders. The Committee was also concerned that the National Police Commission, which is mandated to receive public complaints against law enforcement personnel, [was] weak as it [had] neither powers to summon law enforcement personnel nor the mandate to conduct independent investigations'. ${ }^{15}$

In 2014 the Committee on Economic, Social and Cultural Rights expressed concern 'at violations of human rights in the mining and plantations sectors, including the right to livelihood, the right to food, the right to water, labour rights and cultural rights'; and 'at the lack of an adequate monitoring of the human rights and environmental impact of extractive projects during their implementation. In many cases, affected communities have not been afforded effective remedies and have, along with human rights defenders working on these cases, been subject to violence and persecution. Furthermore, it was concerned that these projects have not brought about tangible benefits for local communities'. ${ }^{16}$

Examining these reports it is relatively clear that Indonesia has a history of serious human rights abuse by its state security forces, police and military, some of which is due to the number of actual armed conflicts and separatist wars fought on its territory. However, in more recent times, in the absence of armed conflict, such conduct can only be analysed in human rights terms as violations of rights to life, freedom from torture, and to basic socio-economic rights to food, water and shelter of individuals and groups who are not engaged in conflict against the state, ${ }^{17}$ which state security forces have perpetrated or helped to perpetrate. While the reports point

\footnotetext{
13 UN Doc. A/62/18 (2007), para. 359.

14 UN Doc. CEDAW/C/IDN/CO/6-7 (7 August 2012), paras. 27-28.

15 UN Doc. CCPR/C/IDN/CO/1 (21 August 2013), para. 16.

16 UN Doc. E/C.12/IDN/CO/1 (19 June 2014), paras. 27-29.

17 Institute of Ecosoc Rights, Dayak Culture Institute (Lebbaga Kebudayaan Dayak, LKD) and the Commission for Justice, Peace, and Integrity of Creation (JPIC) SVD Central Kalimantan (2013).
} 
to the involvement of militias and armed groups in such violations, the instigator and potential 'backer' have often been state security forces. ${ }^{18}$

A partial explanation for this could be the close relationship enjoyed between state security forces and militia, such as Hansip and Wanra, which are regarded as being under the command and authority of state security forces. ${ }^{19}$ Other militia, however, established by companies (such as Pam Swakarsa by Asia Pulp and Paper) and religious/political militia (such as the Islamic militia, Laskar Jihad, and the Christian militia, Laskar Kristus) are independent civilian groups not under military or police command. ${ }^{20}$ Given that militia and armed groups are widely implicated in human rights violations against local communities, it would have been helpful for the Treaty Committees to have paid more attention to the problem of these 'private actors', and their relationship to 'public' authorities.

The picture gained from the above reports is one of a 'militarized state', where the focus of human rights review by UN bodies and agents has been on the abuse of civilians at the hands of state security, with substantial evidence of this occurring in the context of the exploitation of natural resources, including palm oil plantations. Again there is limited evidence in these reports of the involvement of private security actors, though the role of private companies is becoming more evident as the power of the state is gradually rolled back. There remains much blurring, however, between public and private actors especially in the field of security.

\section{Public-Private Distinctions and the Rise of 'Corporate Capture'}

In liberal thought the public-private distinction relates to the spheres of public and private life, whereby the state should not interfere in the private realm. ${ }^{21}$ In legal terms, literature is dominated by 'western legal classifications of public law, which concerns the state, and private law, which regulates relationships between individuals'. ${ }^{22}$ This classification almost immediately demonstrates a problem as to whether a transaction between a state and a private actor, for example a private security contractor, belongs to the realm of public law or private law. Turning to international law, traditionally referred to as 'public' international law, Hilary Charlesworth has written that 'international law operates in the most public of all public worlds, that of nation states'. ${ }^{23}$

\footnotetext{
18 See also Special Rapporteur on Violence against Women, UN Doc. E/CN.4/1999/68/Add.3 (21 January 1999), paras. 40, 44, 56-57, 61, 69, 107; The Working Group on Arbitrary Detention, UN Doc. E/CN.4/2000/4/Add.2 (12 August 1999), paras. 48-49; the Representative of the Secretary General on Internally Displaced Persons, UN Doc. E/CN.4/2002/95/Add.2 (15 February 2002), paras. 10, 19, 30, 54, 62.

${ }^{19}$ Beittinger-Lee (2010), p. 172.

${ }^{20}$ Human Rights Watch (2003). See also Bakker (2017).

${ }^{21}$ Mill (1859).

${ }^{22}$ Charlesworth (1988), p. 191.

${ }^{23}$ Ibid., p. 194.
} 
Orthodox doctrine in international law states that conduct can constitute a 'public' act of state if one of three tests is satisfied: that it is performed by organs or agents of the state; that the conduct itself is inherently governmental; or if the state is in effective control of such conduct. ${ }^{24}$ These tests arguably fail to understand how many post-modern states currently operate. For example, in the UK, numerous functions that were traditionally performed by organs and employees of the state, such as the running of prisons, prisoner escort, and protection services, are outsourced to private companies. $^{25}$

Furthermore, in such states, there may be greater outsourcing and privatisation in some areas of public life such as security, than in others, such as health or education. Different speeds of outsourcing are reflective of what is achievable politically and ideologically, rather than what is legally or ethically acceptable. The number of state organs and agents are reduced and there is little sense of what is 'inherently governmental'. In effect outsourcing is a redrawing, or at least a blurring, of what constitute inherent state functions and, in areas in which outsourcing is deeply entrenched, the government is no longer in effective control of the conduct of private companies. This means that it becomes very difficult to label some type of conduct as an 'act of state' for which the government is legally responsible.

Moral objections to the reduction of a state's inherently governmental functions can be made on the basis, for instance, that even a minimal liberal state should provide security and not contract it out as this may lead to some citizens, or areas within a state, not being covered by security arrangements. ${ }^{26}$ However, the fact remains that governmental hollowing out has clearly occurred in some Western states such as the US. ${ }^{27}$ This has resulted in a reduction in democratic accountability, for instance whereby democratically elected governments pay less attention to the loss of life of private military or security personnel in contrast to the loss of regular soldiers. It also corresponds to an increase of corporate influence on some governments. ${ }^{28}$ In some cases this extends to a situation of 'corporate capture' (discussed below) whereby 'an economic elite undermines the realization of human rights and the environment by exerting undue influence over domestic and international decisionmakers and public institutions'. ${ }^{29}$

Yet, despite these developments in key Western states, which have frequently been mimicked in developing countries, often with outright encouragement by

\footnotetext{
24 Arts. 4, 5 and 8, Articles on the Responsibility of States for Internationally Wrongful Acts 2001.

25 Jones and Newburn (2005).

26 Nozick (1974), p. 113.

27 Stanger (2009).

28 Ibid., p. ix.

29 'Corporate capture' as defined by the Corporate Capture Project of the ESCR-Net Corporate Accountability Working Group, at https://www.escr-net.org/corporateaccountability/corporatecapture (accessed 5 July 2018), which has made submissions to the UN Committee on Economic Social and Cultural Rights (CESCR). The CESCR has recently adopted General Comment No. 24 (2017) on state obligations under the International Covenant on Economic, Social and Cultural Rights in the context of business activities, UN Doc. E/C.12/GC/24 (10 August 2017).
} 
Western states and global financial institutions, ${ }^{30}$ the prevailing orthodox view of the public-private distinction as found in international law is very much based on the concept of a strong sovereign state, one that retains a firm grip, if not monopoly, on the use of force. Although such states clearly still exist, international legal doctrine has failed to adapt to the increasing variety of modern, post-modern, and also pre-modern states.

In this vein, Neil Walker has cogently argued that within the European Union at least, a post-Westphalian phase of sovereignty - what he labels as 'late sovereignty'-has been reached. In this phase, sovereignty is 'no longer so widely or so confidently conceived of as part of the meta-language of explanation and political language'; rather it is 'about a plausible and reasonably effective claim to ultimate authority'. Thus it should be possible to 'imagine ultimate authority, or sovereignty, in non-exclusive terms, ${ }^{31}$

Unsurprisingly, Western states continue to support the orthodox tests for state responsibility since they effectively allow them to outsource their responsibility as well as their functions. In contrast, when it comes to developing states, the story of when conduct is an act of state and when it is a private act follows a different path. In the context of colonialism and decolonisation, Antony Anghie has argued that the 'acquisition of sovereignty by the Third World was an extraordinarily significant event; and yet, various limitations and disadvantages appeared to be somehow peculiarly connected with that sovereignty'. ${ }^{32}$ Anghie's compelling thesis is that sovereignty in the Westphalian sense was not simply extended from European states to newly decolonized states; rather, colonialism helped to shape a new form of sovereignty for this new wave of independent states, one that is 'rendered uniquely vulnerable and dependent by international law, ${ }^{33}$

The embedded nature of the Westphalian concept of sovereignty signifies that its influence persists in core areas such as state responsibility, but this does not match the reality of developing countries. For developing states, like Indonesia, sovereignty is something that has to be continuously fought for and consolidated as the scope and depth of state control fluctuates, with state organs and non-state actors constantly redefining what is public and what is private. It is not so much states giving up their monopoly on the use of force as with the US and UK, but instead developing states are attempting to assert their monopoly through a strong military and then failing to control that force. Although the routes vary and the reasons differ, the net result is that the public/private divide becomes blurred in both Western and developing countries.

The international rules on state responsibility are used in part to determine whether conduct is a 'public' act of state for which the state is legally responsible, or a 'private' act for which the state does not bear direct responsibility. These rules are not well-suited to the turn of the century phenomenon of Western governments

\footnotetext{
30 Estrin and Pelletier (2015).

31 Walker (2003), pp. 17-23.

32 Anghie (2004), p. 2.

33 Ibid., p. 6.
} 
contracting out security functions to private actors, or governments of developing states being unwilling or unable to prevent state actors from undertaking essentially private acts.

\section{Blurring the Distinction in Indonesia: The Issue of 'State Capture'}

Turning to examine the public-private distinction in an important developing state, Indonesia, the norm is not for private security to be operating under a government contract. The situation is that state agents (military and police) provide security services often for commercial gain to a business, or based on a business contract with a militia or private security firm. ${ }^{34}$

This mixture of state and commercial interests not only blurs the public/private distinction, but is also evidence of an intertwining of military and business arrangements. The Indonesian situation is symptomatic of what is known as 'state capture', where powerful individuals or interest groups, such as the military seek to influence the 'rules of the game', i.e. the formation and enforcement of laws and regulation, to protect and promote their own interests. ${ }^{35}$ In the case of Indonesia, it is a longestablished practice that the military self-finances part of its activities. Since independence successive governments have variously endorsed, or chosen to ignore, the military's economic activities, which include inter alia raising funds from militaryowned enterprises and informal alliances, with associated payments from private allies. $^{36}$

Applying the rules of state responsibility on attribution to Indonesian military and security forces, it is clear that they are agents of the state and, if they are violating human rights in the course of their operations, their violations should be considered as acts of state for which Indonesia is responsible. ${ }^{37}$ Under the law of state responsibility if such forces are operating in the private sphere, but continue to use their status as state actors to do so then arguably their conduct remains an act of state. ${ }^{38}$ It may be that Indonesia's security services are not exceeding their authority or contravening instructions when acting for commercial gain, given that the state security forces have been enmeshed in private activities virtually since independence, ${ }^{39}$ but that would make their actions wholly acts of state. Furthermore, even criminal activities engaged in by state security forces, including export smuggling, timber smuggling, illegal logging, illegal mining, extortion, racketeering in drugs, gambling and prostitution, ${ }^{40}$ would be deemed acts of state if they are carried out by state agents

\footnotetext{
${ }^{34}$ Crouch (2007), chapter 11. See footnote 3 for payments made by MNCs to the TNI.

35 Kingsbury (2003).

36 Human Rights Watch (2006).

37 Art. 4, Articles on Responsibility of States for Internationally Wrongful Acts 2001.

38 Ibid., Art. 7.

39 Crouch (2007), p. 274; Robinson (1986), pp. 250-270. For a discussion of the activities of various militias and revolutionary forces from which the Indonesian army emerged during the revolution see: Cribb (1991).

${ }^{40}$ Human Rights Watch (2006), pp. 2, 10-12, 56-59, 63-79.
} 
purporting to act in that capacity. The fact that the Indonesian government has at various points, albeit with little enthusiasm, tried to prohibit, or limit, state security forces for private commercial activities, ${ }^{41}$ does not prevent such actions continuing to be classified as acts of state.

It is undoubtedly the case that the rules on state responsibility were drafted by the International Law Commission (ILC) on the basis that ultra vires activities by state agents are the exception and that normally state security actors operate under constitutional chains of command and control, but practice in Indonesia clearly shows a pattern of behaviour by state security actors at the margins of the public/private distinction. The current complex arrangement of private security providers in Indonesia, include organized militia under state control, militia groups established by companies, independent militia groups employed by companies, local private security companies (often established by retired security personnel), private military and security companies (PMSCs), the TNI (Indonesian military) and Polri (state police), especially Brimob (the paramilitary special operations force). ${ }^{42}$

It could be argued that the jurisprudence invoked by the ILC as justification for the rule, that ultra vires actions of state actors when acting in that capacity continue to be acts of state, is Western-biased as the rules were formulated by claims commissions set up in the early twentieth century to remediate Western individuals and businesses for violations of a claimed international minimum standard while operating in dangerous or violent parts of the globe. ${ }^{43}$ So although the rules may look clearer, in terms of imputing conduct to Indonesia, they lack traction with developing states as they are rules derived from a Western-dominated and largely colonial era.

Other soft law instruments recognize a more complex security picture. The Voluntary Principles on Security and Human Rights (VPSHR) of 2000 acknowledged that in 'many countries, security for [...] large extractive industry projects is provided, at least in part, by state security forces, be they police or military forces' ${ }^{44}$ It goes further to state that 'in some instances, violence and even abuses in and around extractive industry projects have been perpetrated by state security forces'. 'By their nature, state security forces are accountable to the sovereign government, and not

\footnotetext{
41 For example, in 1974 by regulation No. 6/1974; TNI Law No. 34/2004; Presidential Decree No. 43/2009; Human Rights Watch (2010), pp. 1-8.

42 In relation to state organised militia, company militia and independent militia see Human Rights Watch (2003), pp. 6-8, 30, 50-53. On local private security companies see Sciascia (2013), p. 178.

43 Crawford (2002), pp. 107-108, citing Caire Claim (1929) 5 RIAA p. 531. For a similar statement in the human rights context see the Velasquez Rodriguez case, before the Inter-American Court of Human Rights (1989) 95 ILR p. 296.

44 The Voluntary Principles on Security and Human Rights (VPSHR) is a multi-stakeholder initiative consisting of governments, companies and NGOs, which was established in 2000 (and subsequently amended through 2017). It counts just three developing countries-Argentina, Colombia and Ghanaamong its 10 government participants (the others are Australia, Canada, The Netherlands, Norway, Switzerland, UK and US); there are 31 MNCs from the extractive industries and 13 NGOs (as of January 2018).
} 
to the companies' ${ }^{45}$ Although this statement is a more accurate reflection of reality, it still fails to capture the extent and depth of penetration of state security into the commercial sector found in countries like Indonesia.

In any case the VPSHR has limited relevance in Indonesia for two reasons. One is that, aside from the fact that Indonesia is not a participating state, the nonbinding character of the VPSHR renders this instrument somewhat ineffective. The other reason is that company participation is currently focused on extractive industry MNCs, which in the case of Indonesia holds good for company participants like ExxonMobil, Freeport-McMoRan and Rio Tinto, but does not extend to MNCs in the natural resources sector, particularly those engaged with timber and/or agricultural commodities.

Indonesia was an original 'target country' for the VPSHR due to the problems associated with corporate security practices and corruption in such a militarised state. ${ }^{46}$ Over the years, participants in the VPSHR have made efforts to engage with the Indonesian government and extractive industries and companies. ${ }^{47}$ Members of the government pillar have sought to discuss the voluntary principles in meetings with Indonesian government representatives, and members of the corporate pillar have reported on their efforts to disseminate information, engage with local communities and provide training to security providers, including the police.

Since the turn of the century there have been numerous reports of human rights violations against MNCs, like ExxonMobil, Freeport-McMoRan and Rio Tinto and their security providers, supporting the contention that incorporating the VPSHR into company policies and management systems is one thing while improving security practices on the ground is another. Getting the government on board and improving communication with local communities might help. For example, BP included the VPSHR in its agreement with the Indonesian government in relation to the Tangguh natural gas project in West Papua, which included 'an integrated community based security plan', 48 although there are continuing concerns in relation to BP's fulfilment of its human rights commitments. ${ }^{49}$ The VPSHR could potentially have a meaningful role to play in Indonesia if its scope were extended to the MNCs and their subsidiaries in the natural resources sector, especially the palm oil and timber sectors.

\footnotetext{
45 Statement by Voluntary Principles Participants on Memoranda of Understanding Between Companies and State Security Forces (2014), available at http://www.voluntaryprinciples.org/wp-content/uploa ds/2014/10/VPs_-_Statement_on_MOUs.pdf (accessed 5 July 2018).

${ }^{46}$ EarthRights International and The Centre for Environment, Human Rights and Development (2013), p. 9; Hendry and Klein (2010), p. 7.

47 Voluntary Principles Initiative (2015), pp. 18-19.

${ }^{48}$ EarthRights International and The Centre for Environment, Human Rights and Development (2013), p. 20.

49 Vidal (2008).
} 


\section{Public Liability for Private Security}

In the case of purely private military and security companies (PMSCs), which are not hiding behind state authority or exercising governmental functions, it is unlikely that such operators will be acting on the instructions of the Indonesian government, or under its direction and control. Thus, there will be no direct engagement of Indonesian responsibility, except in cases where the security forces have hired groups of thugs to perpetrate violence or intimidation. ${ }^{50}$ In the absence of direct state responsibility for the wrongful acts or omissions of contractors, and mindful of the limits of the second pillar on corporate responsibility of the UN Guiding Principles on Business and Human Rights (UNGPs), ${ }^{51}$ there remains the possibility of identifying due diligence obligations on states, although it is an underdeveloped area. Such obligations could, for example, be extended to regulatory authorities responsible for plantation licences and oversight. The idea is that contracting states (along with host states and, arguably, home states of PMSCs) should fulfil positive obligations (by licensing, monitoring and, where necessary, meting out punishment) to reduce the number of human rights or humanitarian law violations by PMSCs they contract with; or who are based, or operate, within their jurisdictions. ${ }^{52}$

Corporate and individual responsibility for PMSCs is to a large degree dependent on states taking their responsibilities seriously and controlling PMSCs in ways they failed to do for their predecessors (e.g. the trading companies in the 17th and 18th centuries). The Montreux Document of 2008, a non-binding document, is directed at states who engage with PMSCs. It was sponsored by the Swiss government and the ICRC and supported by the major home states of PMSCs as well as a number of host states. ${ }^{53}$ It takes the form of a non-binding instrument (enabling its rapid adoption), which was originally subscribed to by 17 states. By August 2017 the number of participating states had increased to 54, as well as three international organizations (EU, NATO and the OSCE). Indonesia is not a participating state.

The Montreux Document itself points to principles of international law (mainly international humanitarian law) applicable to home, host and contracting states of PMSCs. It does little to deal with the problem of imputability to states of wrongful PMSC conduct as it adopts the narrow orthodox view of state responsibility identified above and makes it clear that contracting with PMSCs does not mean the state is responsible for their actions. ${ }^{54}$ However, the good practices identified in the second part of the Document (including supporting the idea of national licensing schemes for PMSCs) could be seen through a due diligence lens, although they are not currently crafted as obligations upon states. In addition to its narrow focus on armed

\footnotetext{
${ }^{50}$ Human Rights Watch (2006), p. 13; Human Rights Watch (2003), p. 46.

51 Special Representative of the Secretary-General on the issue of human rights and transnational corporations and other business enterprises (2011).

52 White (2012).

53 Montreux Document on Pertinent International Legal Obligations and Good Practices for States related to Operations of Private Military and Security Companies during Armed Conflict 2008, available at https://www.icrc.org/eng/assets/files/other/icrc_002_0996.pdf (accessed 19 July 2018).

54 Ibid., part 1, para. 7.
} 
conflict, and its non-binding nature, the Montreux Document contains no mechanisms for supervision or enforcement, thereby further detracting from its overall effectiveness.

Although Indonesia has not signed up to the Montreux Document, it is under positive obligations derived from the human rights treaties to which it is a party. In its General Comment No. 31 of 2004, the Human Rights Committee observed that obligations under the International Covenant on Civil and Political Rights (ICCPR) 'do not, as such, have direct horizontal effect' between private individuals, but 'the positive obligations on State Parties to ensure Covenant rights will only be fully discharged if individuals are protected by the State, not just against violations of Covenant rights by its agents, but also against acts committed by private persons or entities'. It follows that there will be 'circumstances in which a failure to ensure Covenant rights [...] would give rise to violations by States Parties of those rights, as a result of States Parties' failing to take appropriate measures or to exercise due diligence to prevent, punish, investigate or redress the harm caused by such acts by private persons or entities' ${ }^{55}$

The Committee on Economic, Social and Cultural Rights has taken a similar approach to rights guaranteed under the International Covenant on Economic, Social and Cultural Rights (ICESCR), ${ }^{56}$ when it issued its long-awaited General Comment No. 24 of 2017 on economic, social and cultural rights in the context of business activities. ${ }^{57}$ It deals inter alia with the duties of states to prevent effectively infringements of economic, social and cultural rights in the context of business activities both within their national territories and extraterritorially in situations over which states parties may exercise control. ${ }^{58}$

In this light it is possible to examine the laws and acts of the Indonesian government with regard to private security actors to see if there are any indications that it is taking positive measures to regulate private security providers. National regulations were introduced in 2006 in an effort to regulate private security in response to the increased number of private security providers following rising instability in the country. ${ }^{59}$ Thus, the Regulation of the Chief of National Police No. 17/2006 concerning guidance on the creation of PMSCs sought to control the formation of private security companies and established a licensing system for private security services. ${ }^{60}$ The Regulation of the Chief of National Police No. 18/2006 on Training and the Curriculum of Private Security Guards sought to improve guidelines for the training of guards. ${ }^{61}$ The Regulation of the Chief of National Police No. 24/2007 addressed the management of security systems of organizations, companies

\footnotetext{
55 Human Rights Committee, General Comment No. 31, 'The Nature of the General Legal Obligation', UN Doc. CCPR/C/21/Rev.1/Add.13 (29 March 2004), para. 8.

56 Marks and Azizi (2010), p. 731.

57 UN Economic, Social and Cultural Rights Committee, General Comment No. 24 (2017), 'State obligations in the context of business activities', UN Doc. E/C.12/GC/24 (10 August 2017).

58 Ibid., para. 10.

59 Liss (2014).

60 Ibid.

61 Ibid.
} 
and government offices. ${ }^{62}$ While these regulations represent the first steps to regulate and prevent harm by the private security sector, the police are responsible for administrating the system which, when combined with a lack of resources to support a robust licensing and oversight regime, as well as endemic problems of corruption, seriously undermine efforts to regulate private security providers. ${ }^{63}$

\section{Business and Security in Indonesia}

The human rights jurisprudence discussed at the outset of this article provides very little mention of the problem of private security (either by state actors acting in a private capacity, or by private security companies acting agents for the state), which is surprising given the evidence of such in Indonesia, especially a long history of state security forces effectively hiring themselves out to companies. ${ }^{64}$ Exxon Mobil and Freeport-McMoRan are two high profile MNCs that have caused controversy by making significant payments to the military and police. ${ }^{65}$ Evidence suggests that the payments have been made to both individuals and the institutions; however, this 'commercialization' of the state security sector confuses the institutional role of the military and police with a private security function. It also evidences the extent of state capture, referred to above, in which state (predominantly the military) and corporate interests are entangled. ${ }^{66}$ In this context, it should be noted that while Presidential Decree 63/2004 gives the military and police a mandate for protecting national vital objects, ${ }^{67}$ there is no official policy on MNC payments to state security institutions.

Similarly, no attention has been given to the emergence of local private security companies owned by ex-military officials (such as PT Garuda Prima) and the presence of international private security companies in Indonesia (such as G4S), ${ }^{68}$ as the demand for private security increased following the fall of Suharto and with rising instability in the region. There is mention of the problem of violations of rights, including women's and children's rights on the larger scale plantations, but again this is not linked to private security. ${ }^{69} \mathrm{CSO}$ and media reports implicate private security forces, along with state security forces, in these types of human rights violations although the distinction between the two actors is not always clear.

\footnotetext{
62 Ibid.

63 Ibid.

64 Human Rights Watch (2006), pp. 45-56, 133; Down to Earth (2001); Global Witness (2005); Yunanto (2006), pp. 50-51; Clarke (2008), p. 9.

65 Ibid.

66 Yunanto (2006), p. 50.

67 Decision on Security of National Vital Object, issued by the Coordinating Minister for Political, Legal, and Security Affairs (27 January 2006).

68 For discussion of private security companies in Indonesia see Liss (2014); Sciascia (2013), p. 178; Robinson, Wilson and Meliala (2008).

69 See for example, Amnesty International (2016), p. 148.
} 
Significantly, the separation of the military and police in 2000 removed the police from military control following the implementation of Decree TAP MPR No. VI and VII/1999, whereby the function of internal security was reserved to the police, and the military was made responsible for national defence. ${ }^{70}$ State Defence Act No. 2/2002 and the National Police Act No. 2/2002 further defined the respective roles of the military and police and introduced other institutional reforms to increase civilian control over the military. ${ }^{71}$

However, the separation was not complete-Article 41(2) of the National Police Act left room for the military to assist the police and Article 7.2(b) of TNI Law No. $34 / 2004$ subsequently retained a role for the military to deal with a wide range of external and internal threats, including separatist movements, armed insurgencies, terrorist threats, security threats to the nation and its vital resources, natural disasters and acts of piracy, all of which reflect ongoing concerns over the need to protect national unity and a continued military influence in politics. ${ }^{72}$ The military was unwilling to relinquish the primary role it assumed throughout the Suharto administration with regards to internal security, while the police asserted its increased law enforcement powers and interfered with the military's criminal and business activities. Separating the two security institutions thus increased tensions between them and contributed to rising instability in the country. Whereas the state had restricted private security companies under Suharto, ex-military officials took the opportunity in the reformasi era to establish local private security companies to meet increased demand for private security. ${ }^{73}$

Besides, the involvement of the military in private security is only really hinted at in the reports of the UN and treaty-based human rights bodies discussed at the outset of this article so the line between public and private security, and the human rights implications thereof, are not explored at all. This contrasts with the evidence that it is not just the Indonesian state that is slowly being demilitarized (a process started in the reform period), but also the commercial sector (especially after 2004 and the attempts to restrict military business ownership by virtue of TNI Law No. 34/2004 at least to the extent of establishing some oversight of military businesses). ${ }^{74}$ However, this seems to have just created a space for former military, militias, criminals, businesses and private security actors to exploit. ${ }^{75}$

As has been seen soft law international standards on security and human rights have not had any traction in Indonesia. Similar observations can be made in relation to soft law standards on business and human rights. In an interview with the Business and Human Rights Resource Centre, the Human Rights Commission drew attention to a number of factors impeding the government's ability to promote business and human rights, including: the lack of resources for enforcement, monitoring

\footnotetext{
70 Sukma and Prasetyono (2003), p. 17.

71 Ibid., pp. 17-24.

72 Amnesty International (2009), pp. 17-18.

73 Robinson, Wilson and Meliala (2008), pp. 3-5.

74 Human Rights Watch (2010), p. 8.

75 Robinson, Wilson and Meliala (2008), pp. 2-4.
} 
and prosecution; opposition by economic interest groups, business associations and influential people outside government; opposition and lack of consensus and awareness in government; political limitations imposed by foreign governments or multilateral institutions; concern about deterring foreign investment; and other challenges in coordinating government and lack of capacity. ${ }^{76} \mathrm{~A}$ number of reasons, representing the different priorities and competing interests within Indonesia's post-Suharto democracy thus help to explain the slow progress being made in the development of human rights policy for the country's corporate sector.

The UNGPs, another non-binding international instrument, were developed by John Ruggie as a global standard for preventing and addressing the risk of adverse impacts of business activities on human rights based on the 'protect, respect, and remedy' framework. ${ }^{77}$ The UNGPs are formulated in three mutually enforcing pillars. Pillar I outlines the duty of states to establish binding rules to promote respect for human rights by non-state actors, including businesses, and identifies ways for states to discharge their duty more effectively. ${ }^{78}$ Of particular note is that under Pillar I, the UNGPs address the state-business nexus, by requiring in Guiding Principle 4 that 'States should take additional steps to protect against human rights abuses by business enterprises that are owned or controlled by the State [...] including, where appropriate, by requiring human rights due diligence'. ${ }^{79}$ Guiding Principle 4 could apply to the Indonesian extractives and natural resources sector where the government or a state entity (possibly including the military) has a share, or is a partner, in the business enterprise.

Moreover, Guiding Principle 5 requires that 'States should exercise adequate oversight in order to meet their international human rights obligations when they contract with, or legislate for, business enterprises to provide services that may impact upon the enjoyment of human rights' ${ }^{80}$ Here again, where the government of Indonesia has entered directly into an concession contract or licence with an MNC in the extractive or natural resources sector, it remains under a continuing obligation with respect to the protection of international human rights in its territory.

Pillar II spells out the implications of the corporate responsibility to respect human rights. Guiding Principle 11 requires business entities to avoid infringing on the human rights of others and to address any adverse human rights impacts with which they are involved. ${ }^{81}$ This means not only those adverse human rights impacts that may occur through a company's own business activities or entities within a

\footnotetext{
76 Business and Human Rights Resource Centre (2018).

77 Special Representative of the Secretary-General on the issue of human rights and transnational corporations and other business enterprises (2011).

78 Ruggie (2013), p. 84.

79 Special Representative of the Secretary-General on the issue of human rights and transnational corporations and other business enterprises (2011), Guiding Principle 4; the Commentary makes clear that where acts of a business enterprise "can be attributed otherwise to the State, an abuse of human rights by the business enterprise may entail a violation of the State's own international law obligations'.

80 Ibid., Guiding Principle 5; again the Commentary points out that 'States do not relinquish their international human rights law obligations when they privatize the delivery of services that may impact upon the enjoyment of human rights'.

81 Ibid., Guiding Principle 11.
} 
business enterprise, such as subsidiaries, but also any adverse impacts that may be linked to a company's broader business relationships. ${ }^{82}$ Of significance is the introduction of this requirement for all business enterprises, irrespective of their size, the nature and context of its operations. ${ }^{83}$ Thus, logging and palm oil plantation businesses in Indonesia, which are either owned or controlled directly by MNCs, or through local subsidiaries, are covered equally.

Similarly, such companies and/or their subsidiaries need to have in place a human rights due diligence process to identify, prevent, mitigate and account for how they address their impacts on human rights, as set out in Guiding Principle 17. This requirement even extends to third-party suppliers in their supply chains. ${ }^{84}$ Again, human rights due diligence will be significant in the upstream supply chain, i.e. from the plantation to the mill and the port, in Indonesian oil palm plantations or logging operations.

Pillar III affirms that states must ensure access to effective judicial remedy for human rights abuses and that business enterprises should establish or participate in effective grievance mechanisms for individuals and communities that may be adversely impacted. ${ }^{85}$ In this context, the Office of the United Nations High Commissioner for Human Rights, at the request of the Human Rights Council, has produced a report on improving accountability and access to remedy for victims of business-related human rights abuses. ${ }^{86}$

In order to disseminate and promote the implementation of the UNGPs, the Human Rights Council established the Working Group on the issue of human rights and transnational corporations and other business enterprises in June 2011. ${ }^{87}$ The Working Group called on states to develop National Action Plans on Business and Human Rights (NAPs) to demonstrate their implementation of the UNGPs, ${ }^{88}$ and provided guidance in December 2014 (updated in November 2016). ${ }^{89}$

Encouragingly, Indonesia became the fifteenth state and the first Asian country to launch its NAP on 16 June 2017. ${ }^{90}$ The Indonesian National Commission for Human Rights (Komnas HAM) began developing the NAP in September 2014 in response to the lack of focus on corporations in the National Plan of Action for the Promotion and Protection of Human Rights and increasing land conflicts and human rights abuses involving corporations. ${ }^{91}$ It was completed following a multistakeholder

\footnotetext{
82 Ibid., Guiding Principle 13(a) and 13(b).

83 Ibid., Guiding Principle 14.

${ }^{84}$ Ibid., Guiding Principle 17; see also the Commentary to Principle 17.

85 Ruggie (2013), p. 102.

86 Improving accountability and access to remedy for victims of business-related human rights abusesReport of the UN High Commissioner for Human Rights, UN Doc. A/HRC/32/19 (10 May 2016), paras. 24-28.

87 Resolution A/HRC/RES/17/4.

88 Twenty-third Session of the Human Rights Council, UN Doc. A/HRC/23/32 (27 August 2013), p. 21.

89 UN Working Group on Business and Human Rights (2016).

90 Business and Human Rights Resource Centre (2017).

91 'Human rights guidelines prepared for businesses', The Jakarta Post, 20 June 2015, at http://www. thejakartapost.com/news/2015/06/20/human-rights-guidelines-prepared-businesses.html (accessed 5 July 2018).
} 
effort between Komnas HAM, relevant government ministries (e.g. the Ministry for Industry), institutions [e.g. the Institute for Policy Research and Advocacy (ELSAM)], business groups and civil society [e.g. the Foundation for International Human Rights Reporting Standards (FIHRRST)]. ${ }^{92}$

Various actors believe that the government should develop coherent legislation to ensure that both the government and companies fulfil their responsibilities under the UNGPs. They hope that the NAP will provide the necessary impetus for further legislation at the presidential level to protect human rights from the negative impacts of business operations. ${ }^{93}$ Rather than leaving responsibility for human rights with companies, and given the lack of operational impact of corporate efforts thus far, it is felt that the role of the state should be enhanced to support the implementation of the UNGPs and regulate corporate behaviour. ${ }^{94}$ However, any readjustment of the relationship between the state, corporate actors and individual must address the role of the security sector if meaningful progress is to be made towards reducing human rights violations in the natural resources industry, including the agricultural commodities sector.

As recognized by the embassy representative for the Netherlands, successful implementation of the UNGPs not only depends on the necessary government legislation but a change in corporate culture so that companies recognize the Guiding Principles as a moral concern rather than legal issue. ${ }^{95}$ Inevitably, however, market forces will help to motivate companies to take their human rights responsibilities more seriously. ${ }^{96}$ Timber certification has improved the competitiveness of Indonesian wood. ${ }^{97}$ There are increasing concerns for the palm oil market following European palm oil initiatives, including the non-binding European Parliament Resolution on Palm Oil and Deforestation of Rainforest adopted on 4 April 2017. ${ }^{98}$

In contrast to the UNGPs, there is no evidence that private security companies operating in Indonesia have engaged with the relevant international standards contained in the International Code of Conduct for Private Security Providers (ICoC) of 2010. Although it is not binding on PMSCs, the Code does detail the human rights that PMSCs are expected to respect (including restrictions on the use of force and torture). Further, it requires PMSCs to exercise due diligence in vetting and training of employees as well as having grievance procedures and effective remedies to victims of abuse.

\footnotetext{
92 Foundation for International Human Rights Reporting Standards (2017).

93 Ibid.

94 Ibid.

95 Ibid.

96 The Institute for Policy Research and Advocacy (2017).

97 Indonesia became the first country to issue a FLEGT (Forest Law Enforcement, Governance and Trade) licence, on the basis of a Voluntary Partnership Agreement with the EU, pursuant to Regulation (EU) No. 995/2010 of the European Parliament and of the Council of 20 October 2010 laying down obligations of operators who place timber and timber products on the market [2010] OJ L 295/23-34.

98 European Parliament Resolution on Palm Oil and Deforestation of Rainforests, 2017/2222(INI) (04/04/2017).
} 
In September 2013, a governance and oversight mechanism was established as an Association under Swiss law: the International Code of Conduct Association (ICoCA) based in Geneva. The ICoCA Board of Directors, made up of representatives of states (US, UK Australia, Canada, Norway, Sweden, Switzerland), industry and civil society organizations, is responsible for developing procedures for certification, monitoring, reporting, assessing performance and addressing complaints. The Association is empowered to request a member company to take corrective action to remedy non-compliance with the Code within a specified time period. A non-compliant company may suffer suspension or termination of membership. ${ }^{99}$ of the 600 or so companies that signed up to the ICoC only 95 have joined the ICoCA, with none from Indonesia. ${ }^{100}$ Only by being a member of the ICoCA will a PMSC be required to meet agreed international standards. At the Board meeting in March 2016 'the Certification Committee continued discussions regarding challenges faced by Members wishing to become certified to currently-recognized standards'. Challenges 'included access to standards (particularly for PSCs operating in the "Global south" and non-English speaking regions) as well as the cost of certification'. ${ }^{101}$ Despite these difficulties the Certification Process opened on 1 November 2016, recognising PMSCs with independent accredited certification to US standards (PSC 1) as well as international ones (ISO 28007, ISO 18788). ${ }^{102}$ There are procedures for reporting, monitoring and assessing accredited PMSC performance, including provision for field based reviews. ${ }^{103}$

The specific issue of business and security has been more squarely put before the UN's Human Rights Council by a written statement submitted in 2016 by the Asian Legal Resource Centre (ARLC), an NGO with consultative status before ECOSOC, entitled 'Indonesia: Lack of human rights policy in business sectors' ${ }^{104}$ The ARLC pointed to instances of "chaos and conflict between security forces and the local community $[\ldots]$ as the community strives to reclaim the land being used by these companies and struggles for the right to a healthy environment'. It also emphasised that 'the increasing number of agrarian conflicts in the plantation area is evidence of the expansion of large-scale plantations in Indonesia. It also noted that one of the biggest commodities in plantation areas is palm oil'; and that 'the majority of human rights violations in the agrarian sector and natural resources were committed by the Police and Military. The pattern of violations is fabrication of charges, land confiscations, violence and torture, and shooting to death'. ${ }^{105}$

\footnotetext{
99 Arts. 10-12, Articles of Association, International Code of Conduct for Private Security Providers' Association 2013.

100 See http://www.icoca.ch/en/membership?view_type=map (accessed 5 July 2018).

101 See http://www.icoca.ch/sites/default/files/uploads/2016\%20Q1\%20Update.pdf (accessed 5 July 2018).

102 See https://icoca.ch/en/certification (accessed 5 July 2018).

103 See https://icoca.ch/en/monitoring (accessed 5 July 2018).

104 UN Doc. A/HRC/32/NGO/51 (2 June 2016).

105 Ibid. See also written statement submitted by the Asian Legal Resource Centre, UN Doc. A/HRC/26/ NGO/66 (5 June 2014), para. 7: 'Land grabbing, especially for Palm oil, has emerged as a serious issue in Indonesia as well and is threatening scores of small farmers with imminent loss of their livelihood opportunities'.
} 
Although this statement places the role of business at the heart of Indonesia's human rights problems, and it recognizes the role of the state security apparatus in the expansion of the natural resources and mining sectors at the expense of the local populations, it does not identify the blurring of the line between the state and private security as being an issue. To be able to exert control over human rights abuses, it is important to identify the functions of the state and those of the private sector; to determine when the acts of private actors are attributable to the state; but also to recognize that the government still has positive obligations to regulate the private sector in order to prevent human rights abuses.

\section{Human Rights Violations by Security Actors}

Numerous violations of human rights obligations by state security actors working for MNCs in the natural resources sector, including agricultural commodities, have been reported. They include arbitrary and unlawful deprivation of life, torture and other cruel, inhuman or degrading treatment, forced disappearances, arbitrary arrest and detention, restrictions on peaceful assembly and association, forced evictions, denial of customary land rights, destruction of livelihoods, and environmental pollution. Some specific examples drawn from publicly available information are given here to highlight the nature and extent of the problem:

- During the 1980s and 1990s, land was unlawfully seized from the indigenous Malay and Sakai communities in Riau province of Sumatra for the PT Arara Abadi plantation. The military and police used intimidation and violence to forcibly evict local people from community lands. ${ }^{106}$

- In 1995, the Australian Council on Overseas Aid, an Australian non-governmental organization, reported that military and mine security personnel were involved in the deaths and disappearances of indigenous people within Freeport's mining concession. ${ }^{107}$

- In 2001, a man was shot and killed, and in 2002 another was seriously injured, by Brimob forces working at PT Indo Muro Kencana owned by Australia's Aurora Gold. ${ }^{108}$ The mine has a long history of land conflicts with indigenous Dayak people, who were forcibly removed from the land and their housing and equipment destroyed. ${ }^{109}$

- In 2004, during protests against forcible evictions at Newcrest's Halmahera mine, Brimob forces killed one person, shot another and assaulted a number of others. ${ }^{110}$

\footnotetext{
106 Human Rights Watch (2003), pp. 3-4.

107 Leith (2003), p. 6.

108 Down to Earth (2002).

109 Down to Earth (1999).

110 Down to Earth (2004).
} 
- On 11-12 July 2009, three people were killed near Freeport's Grasberg mine. Indonesian authorities attributed responsibility to the Free Papua Movement but doubts were cast on those claims when police recovered military and police grade bullet casings from the scene. ${ }^{111}$

- In October 2011, in further clashes at Freeport's Grasberg mine, police and security forces shot at protesters, who were striking against the minimum wage and blocking access for replacement workers, killing one person and wounding others. ${ }^{112}$

- In 2012, Brimob officers working for the palm oil company, PT Agro Bukit, shot and killed a person when he was fleeing with other villagers who had gone to the plantation to enquire about the arrest of local farmers. ${ }^{113}$

- In 2012, state security forces working for Kaltim Prima Coal mine in 2012 assaulted workers who were protesting against the company's failure to implement a human rights agreement at the mining concession. ${ }^{114}$

- Throughout 2016-2017, several allegations have been made against Brimob forces concerning the use of force and intimidation while evicting local people from community lands. ${ }^{115}$ For instance, in July 2016, Brimob forces assisted PT Musi Hutan Persada in the forcible evictions of the Cawand Gumilir villagers in Musi Rawas, South Sumatra during the hostile takeover of productive land. ${ }^{116}$

- In November 2017, Indonesian NGOs issued a press release claiming that RSPO (Round Table on Sustainable Palm Oil) member ANJ used Brimob personnel on several occasions to violently repress protests by indigenous Iwaro people demonstrating against the takeover of their land without consent for palm oil cultivation by ANJ subsidiary PT Permata Putera Mandiri. ${ }^{117}$

Fieldwork undertaken by several of the authors, employed by the Indonesian NGO (Inkrispena), and supported by the Dutch NGO (SOMO, or the Centre for Research on Multinational Corporations) explored the relationship between security providers and two MNCs involved in the exploitation of natural resources in the agricultural commodities sector and embroiled in numerous instances of human rights violations. ${ }^{118}$ The full report includes the results of the two case studies: one

\footnotetext{
111 Business and Human Rights Resource Centre (2009).

112 'Miner shot dead in Indonesian strike', Al Jazeera, 10 October 2011, at http://www.aljazeera.com/ news/asia-pacific/2011/10/2011101052724758754.html (accessed 5 July 2018).

113 Rainforest Rescue Petition (2014).

114 London Mining Network (2013).

115 Forest Peoples Programme (2016a, b).

116 'Stop Funding for PT Musi Hutan Persada Depriving People's Rights', Walhi Press Release, 23 April 2016, at https://translate.google.co.uk/translate?hl=en\&sl=id\&u=http://walhi-sumsel.blogspot. com/\&prev=search (accessed 5 July 2018)

117 Forest Peoples Programme (2017).

118 For full report see SOMO and Inkrispena (2017).
} 
involving palm oil company Asiatic Persada (AP), owned by the Ganda Group, and one involving logging company Wirakarya Sakti (WKS), owned by the Sinar Mas Group, both Indonesian subsidiaries of larger MNCs. These two case studies, which involved fieldwork in Sumatra in July and August 2016 supplementing publicly available information, reveal a pernicious and deliberate erosion and violation of the rights of local inhabitants across the spectrum of security actors, showing that public security actors are protecting corporate interests rather than performing public functions. ${ }^{119}$

\section{Case Study on Palm Oil and Security}

The first case study revealed a conflict between PT Asiatic Persada (AP), a palm oil company owned by the Indonesian conglomerate Ganda Group, and the indigenous Suka Anak Dalam (SAD) people and former migrant populations involving 3550 ha of AP's 20,000 ha palm oil concession in Jambi province Sumatra, with a focal point being the village of Bungku. ${ }^{120}$ Throughout the social and land conflict involving the SAD communities that live in the AP plantation, these communities have experienced violent action against them from both private and public security actors. These incidents have involved AP staff, its security personnel, and Indonesian security forces in the form of police, the mobile police brigade (Brimob), and the Indonesian military (TNI). The research work produced a detailed, but non-exhaustive overview, of the harassment and intimidation that has taken place in the area in the past years. ${ }^{121}$ Reportedly, the conflict between AP and the SAD population living on or near their concession has been smouldering since 2000, with the company and the communities claiming ownership of the same area. ${ }^{122}$

AP employs its own security personnel, in varying capacities. In July 2011, AP hired the mobile police brigade (Brimob) to increase the security of their plantation. ${ }^{123}$ A month later on 8 August, a violent confrontation took place over allegations of a local resident stealing the company's palm fruit. This resulted in an escalation of confrontation between Brimob and a number of villagers resulting in the firing of weapons, injuries, the setting alight of the accused's house and the eviction, looting and bulldozing of over eighty residences by AP personnel. ${ }^{124}$

More than 100 people that fled the scene took up shelter in the neighbouring forest and nearby villages, with food aid and plastic shelters being provided by the Indonesian Department of Social Affairs, but only after 20 days. ${ }^{125}$

\footnotetext{
119 Ibid.

${ }^{120}$ Ibid.

${ }^{121}$ Ibid.

122 Steinebach (2013).

${ }^{123}$ Forest Peoples Programme (2011).

${ }^{124}$ Ibid.

125 Ibid.
} 
Beyond the violence inflicted upon Bungku's inhabitants, the presence of AP's private security personnel in the area, backed up by state security, constantly reminds the villagers of the company's presence and power, causing them to further fear for their safety. For example, in 2011, following the confrontation, Brimob personnel undertook frequent patrols of the communities in the area, with one of Bungku's hamlets visited twice daily by 6-10 armed policemen. They reportedly approached homes, verbally abusing and threatening to shoot the inhabitants while firing their weapons into the air. It was said that interviewees from Bungku felt terrorised by the actions of the police. ${ }^{126}$

Bungku is beset on all sides by the concessions of four companies, all with their own private security personnel. The different security forces are not easily identifiable, as most do not wear insignia indicating which company they work for. Meanwhile, security personnel guard roads leading to and on the plantation. AP's security guards are known to drive through Bungku in their $4 \times 4$ trucks at high speed, causing dust in the road to come up which in turn causes breathing and visibility issues, as well as soiling villagers' clean clothes hung out to dry. ${ }^{127}$

In December 2013, 8 months after AP was sold by Wilmar to the Ganda Group, 1500 state security personnel, a mix of Brimob and TNI members, reportedly drove 500 SAD families from their land, ${ }^{128}$ and looted and destroyed at least 295 houses. ${ }^{129}$ Allegations were made that this had been done under orders of AP, and that the company had paid soldiers and police to clear the land. ${ }^{130}$ SAD villagers stated that during the eviction their savings and other belongings had been looted, and their livestock killed. ${ }^{131}$ Between December 2013 and March 2014, 700 huts and houses of communities in conflict with AP were reportedly destroyed by the police and military.

In February 2014, when thousands of evicted community members attempted to return to what they perceive as their indigenous land, they were blocked by the police and the TNI or Indonesian military. According to subsequent reports, the land has remained inaccessible to the former inhabitants, with AP's security staff guarding it. ${ }^{132}$ The most recent widely reported violent incident between the SAD and AP took place on 6 March 2014 when a Bungku inhabitant was abducted from his home by six personnel from the TNI. He was taken to one of AP's security posts where he was stripped and beaten, and made to lick his own blood off the floor. ${ }^{133}$ This was because he had witnessed the military removing signposts which demarcated

\footnotetext{
126 Ibid.

127 SOMO and Inkrispena (2017), interview with village chief, location and date withheld for safety.

128 Rainforest Rescue (2014).

129 Ibid.

130 Ibid.

131 Ibid.

132 Rainforest Rescue (2014); Global Forest Coalition (2013).

133 Amnesty International (2015).
} 
contested land in the area, by identifying that land as claimed both by local communities and by two subsidiaries of AP. During the beating, local police officials present at the security post watched the physical abuse without intervening. ${ }^{134}$ According to Indonesian NGOs, Walhi and Kontras, the targeted individual had long been involved in the confrontation between $\mathrm{AP}$ and the SAD, and was abducted for opposing AP. According to his lawyers, the military personnel beat and tortured him both on route to and at AP's facilities. ${ }^{135}$ Villagers demanding his release were beaten, kicked and stun guns were used against them by AP's security staff and TNI personnel. ${ }^{136}$ One of those villagers was taken by the military and company security, who bound his hands before beating him to death. ${ }^{137}$ Other villagers protesting about the abduction were chased off by the military, who threatened to shoot them. ${ }^{138}$

The Palembang Military Court sentenced each of the six soldiers involved in the killing to 3 months in prison. The Palembang Military Court's judgment stated that the soldiers' mandate in Jambi province had been to prevent conflict between the SAD and AP in Bungku village. ${ }^{139}$ The trial by Military Court has been heavily condemned by Indonesian NGO Kontras, who stated that it was not conducted according to law, and that the sentences imposed on the military personnel were unfairly lenient. Five of AP's private security personnel were arrested by Jambi's regional police and charged with violence resulting in the individual's death. ${ }^{140}$

The above mentioned security incidents are directly related to the vulnerable position of local communities. In a paper analysing the complaints pertaining to Wilmar's palm oil plantations, including the AP case, it was concluded that the deeper-seated problems facing people affected by the palm oil sector can be exacerbated by patterns of violence and intimidation by state and non-state actors, who can be deployed to 'protect' palm oil plantations from people who 'occupy' them, or to harvest fruit that is legally considered the property of the company. ${ }^{141}$ More specifically, the arrests (for theft of oil palm in Jambi) involve company security guards working together with local police, reinforcing a widely held perception that the police effectively act as an extension of the company. ${ }^{142}$

\footnotetext{
134 SOMO and Inkrispena (2017), interview with female interviewee, location and date withheld for safety.

135 Ibid., interview with National Peasant Union, location and date withheld for safety.

136 Ibid., interview with female interviewee, location and date withheld for safety.

137 Amnesty International (2015).

138 SOMO and Inkrispena (2017), interview with female interviewee, location and date withheld for safety.

139 SOMO and Inkrispena (2017), in a verdict of military court, it is said that the six soldiers (the defendants) acted on the basis of a letter of command order number Sprin/21/II/2014 (5 February 2014), and a letter of command order number Sprin/36/III/2014 (1 March 2014), on the deployment of military personnel of 142/KJ Infantry Battalion.

140 Ibid.

141 Balaton-Chrimes and Macdonald (2016), p. 26.

142 Institute for Policy Analysis of Conflict (2014), p. 23.
} 


\section{Case Study on Logging and Security}

The second case study found a social and land conflict existed between PT Wirakarya Sakti (WKS), a logging company owned by the Indonesian Sinar Mas Group, and communities living close to its concessions in four separate villages, in three of Jambi's regencies. Community members who were interviewed expressed animosity towards WKS, stating the company had caused them to lose land and livelihood, as well as the loss of their way of life, and pointed to the death and criminalization of their fellow community members by company security, Brimob and the TNI. ${ }^{143}$ The focus here is on one of the villages that was the subject of particular investigation during the fieldwork.

Lubuk Mandarsah is a village consisting of 10 separate hamlets, some of which reportedly overlap with WKS' concession in the area. WKS' presence in the area was first noticed in 2006, when the company announced that it would be constructing roads through the area. After the roads were finished that same year, WKS personnel reportedly returned to Lubuk Mandarsah and, accompanied by the TNI, evicted several villagers and cleared their cultivated land, thereby destroying their livelihoods. ${ }^{144}$ In the following 2 years, the remaining villagers were often visited by military personnel, who verbally intimidated them and fired their weapons into the air in an effort to scare them from the area. ${ }^{145}$

In 2008, the conflict intensified as Lubuk Mandarsah's inhabitants repossessed part of the land WKS had claimed as their concession, and in 2009 when they burned some of WKS' heavy equipment as well as a fuel truck. Following the burning, several Brimob trucks came to the village with arrest warrants for 11 villagers, but left without detaining anyone. ${ }^{146}$ In 2013, Lubuk Mandarsah's villagers reclaimed another portion of land previously taken by WKS. Interviewees stated that in response to this, WKS deployed the so-called Rapid Response Force (URC) of WKS's security company PT Mangala Cipta Persada (MCP) to this part of the concession, after which villagers were often visited at home by URC personnel and otherwise intimidated into leaving the area. ${ }^{147}$ The tensions between Lubuk Mandarsah's community and WKS' security came to a head when, in February of 2015, several URC personnel beat a local union organizer to death. The organizer's body, hands tied together behind his back, was found the next day in a nearby swamp. He had been beaten and then had a rope tied around his neck, which led to his suffocation and death. ${ }^{148}$

\footnotetext{
143 SOMO and Inkrispena (2017).

144 Ibid., interview with several interviewees, location and date withheld for safety.

145 Ibid., interview with several interviewees, location and date withheld for safety.

146 Ibid., interview with several interviewees, location and date withheld for safety.

147 Ibid., interview with several interviewees, location and date withheld for safety.

148 Ibid.
} 
As a result of the court case covering the incident, five URC personnel were sentenced to prison for periods varying from eight to 15 years. It was noted by the Indonesian NGO Walhi that during the court proceedings no attention was paid to the question of whether the URC personnel had been acting under instructions to use force if necessary. Reportedly, the judges assumed that URC personnel had acted violently at their own volition. Furthermore, no representatives of WKS or MCP attended the proceedings. ${ }^{149}$

Following the murder, WKS' sole customer Asia Pulp and Paper (APP) stated that they 'gave instructions' to WKS' management to suspend all security personnel implicated in the incident, as well as the head of security at MCP. ${ }^{150}$ In APP's Sustainability Report 2015, the company's managing director stated that he was 'deeply saddened by the death of a community member in Jambi, following an altercation with a third-party security contractor working for one of APP's pulpwood suppliers, Wira Karya Sakti (WKS)'. APP's managing director also stated that 'WKS ceased its contract with the security contractor and responded to the recommendations made by [...] KOMNAS HAM. Following independent advice from NGOs and third-party security experts we have also developed and implemented improvements to our security arrangements across the organization'. ${ }^{151}$

Towards the end of 2015, WKS hired another company for their private security, known as Bima. Several months later, Bima was replaced by international security company G4S, which is now responsible for security at WKS' concession. ${ }^{152}$ However, MCP is still employed by other Sinar Mas subsidiaries in the area and several former MCP employees are now employed by G4S. Reportedly, G4S has provided more information and training to its employees on Indonesian legislation and the company's code of conduct to which they must adhere. ${ }^{153}$

Considering both cases studies together, it can be concluded that the rule of law is not functioning in the areas of operation of both AP and WKS. The Indonesian security forces, as well as private security companies, do not protect local people's rights but, instead, seem focused on protecting corporate interests. This has allowed company security personnel to operate with near impunity, while public security officials add to the violence. In the case of WKS, it is unclear if the situation on the ground has improved after G4S was hired in 2015 to take over the security management of the WKS concession.

\footnotetext{
149 Ibid.

150 Ibid.

151 APP (2015).

152 SOMO and Inkrispena (2017), public relations staff for WKS in district 8 confirmed this information. Information obtained after village Community Meeting.

153 Ibid, interview with male interviewee, interview with community members, and interview with Indonesian NGO, locations and dates withheld for safety.
} 


\section{Accountability and Access to Justice}

The problems in applying the rules of state responsibility to Indonesia, where the public/private distinction is blurred, have already been alluded to. There is also limited evidence of the other two forms of applicable legal responsibility-corporate responsibility and individual responsibility-being implemented in Indonesia. The case studies show that the perpetrators of violence often go unpunished but, even where subject to criminal charge, disproportionately low sentences are handed down. There is also little engagement by the companies concerned in terms of accountability, although in one case study criminal behaviour led to the private security company losing its contract.

There is limited evidence of victims having access to justice for human rights violations committed by the state, military, police and companies. In August 2015, President Joko Widodo established a 'reconciliation commission' to investigate past human rights abuses. However, the reconciliation commission is not a judicial body but a state body led by the Attorney General, whose office has consistently prevented human rights cases from going to court. It is also dominated by the military, police, intelligence agency and the Ministry of Politics, Law and Security. ${ }^{154}$ Disappointingly, the mandate of the commission was limited to genocide, crimes against humanity and war crimes, excluding torture, forced disappearances and extra-judicial executions. Victims of atrocities, such as the communist killings of 1965-1966, the numerous abuses in Aceh and Papua, the violence following the East Timor referendum, ${ }^{155}$ and incidents during the fall of President Suharto, have yet to receive a remedy or even an apology from the state. The lack of progress towards an accountability framework for human rights violations by the military and police prompted the US and Australia to repeat their concerns in the UN Periodic Review working group. ${ }^{156}$

Other potential avenues of redress have been ignored by the government, including the indictment of General Wiranto, who was chief of Indonesia's armed forces at the time of the East Timor referendum violence, along with other military officials, for crimes against humanity by the United Nations-sponsored Special Panel for Serious Crimes of the Dili District Court. ${ }^{157}$ With such major atrocities remaining unaddressed, there seems little prospect of the continuous lower level violence (sometimes leading to deaths), intimidation and abuse identified in the above research being accounted for.

Furthermore, there has been little reform of military justice, as required by the second amendment on reform Law No. 31/1997, ${ }^{158}$ allowing military personnel to

\footnotetext{
154 Setiawan (2016).

155 Dodd (2002).

156 UN General Assembly, Report of the Working Group on the Universal Periodic Review: Indonesia, 14 July 2017, Human Rights Council Thirty-sixth Session 11-29 September 2017, UN Doc. A/ HRC/36/7, pp. 5-6.

157 Dodd (2002)

158 Reza (2015).
} 
continue to enjoy a degree of impunity and limiting access to justice for victims. Although military courts have been brought under the supervision of the Supreme Court, ${ }^{159}$ reform stalled following opposition to limitations on the jurisdiction and authority of military courts. Currently, military personnel cannot be tried in civilian courts unless they have collaborated with a civilian when committing a crime whereupon they may be subject to joint military-civilian investigation. ${ }^{160}$ Military courts have jurisdiction to prosecute all crimes committed by military personnel but can only apply the Military Penal Code or the general Criminal Code, which excludes a number of criminal laws outside the Criminal Code and thereby restricts the criminal liability of military personnel. ${ }^{161}$ Although the Human Rights Court may assert jurisdiction in relation to allegations of genocide and crimes against humanity, it has no capacity in relation to other human rights violations. ${ }^{162}$

When investigations are carried out and military personnel are found guilty under the present system of military justice, they tend to receive lenient sentences that fail to reflect the severity of the crime. For instance, six TNI personnel were sentenced to only 3 months in prison for abducting and torturing one person, killing another person and assaulting six farmers, who were involved in long standing land conflicts with AP. ${ }^{163}$ When eleven police officers and three civilians were killed during the armed confrontation between the police and military in Binjai because the police refused to follow military orders to release a military-backed drug dealer, the military prosecuted twenty low-ranked soldiers who were discharged and received prison sentences of only 5-30 months. ${ }^{164}$

In relation to remedies at the company level, companies have been able to circumvent mediation channels such as the Compliance Advisor Ombudsman (CAO), the independent recourse mechanism for the International Finance Corporation (IFC) and Multilateral Investment Guarantee Agency (MIGA), ${ }^{165}$ and the complaint mechanism of the Round Table on Sustainable Palm Oil (RSPO). ${ }^{166}$ In one of the case studies described above, on the palm oil company Asiatic Persada (AP), complaints were filed to both the CAO and the RSPO by a coalition of NGOs concerning a land conflict with the SAD local communities.

\footnotetext{
159 National Report Submitted in Accordance with Paragraph 5 of the Annex to Human Rights Council Resolution 16/21: Indonesia, 20 February 2017, Human Rights Council Working Group on the Universal Periodic Review, Twenty-seventh Session 1-12 May 2017, UN Doc. A/HRC/WG.6/27/IDN/1, para. 127.

160 Ibid, para. 135 explaining the 'connectivity mechanism' introduced in the Criminal Proceeding Code and Law No. 48 of 2009.

161 Human Rights Watch (2013).

162 Ibid.

163 US Department of State, Bureau of Democracy, Human Rights and Labor (2014).

164 Human Rights Watch (2016), pp. 67-70.

165 CAO's mission is to address complaints by people affected by IFC/MIGA projects and to enhance the social and environmental accountability of both institutions.

166 The RSPO was established in 2004 in response to rapid deforestation to move towards sustainable palm oil production, including respect for customary land rights and conflict resolution. See also Amnesty International (2016), p. 11 on 'Failure of the RSPO in the case of Wilmar', and pp. 90-93 on 'Hiding behind the RSPO: a weak voluntary initiative'.
} 
Wilmar, one of the largest palm oil conglomerates in the world and the owner of AP, sold the company in 2013 while mediation talks were still ongoing, and did so without any consultation. AP was sold to Prima Fortune International Ltd and PT Agro Mandiri Semesta (owned by the Ganda Group, an Indonesian conglomerate owned by the brother of one of the founders of Wilmar), which has no relationship with the IFC, nor is a member of the RSPO, making resolution of the conflict in favour of the victims unlikely. ${ }^{167}$ The sale of AP by Wilmar has effectively halted the mediation attempt with the affected communities. Community members and NGOs involved in the case are concerned that selling AP to "non-Wilmar, nonRSPO member and non-IFC funded companies' jeopardizes efforts to resolve the conflict as the new owners may not feel obliged to continue the IFC-mediated talks and are not bound by RSPO and IFC standards. ${ }^{168}$

Civil cases have been filed in the US against Exxon Mobil and Freeport-McMoRan under the US Alien Tort Statute (ATS). The International Labour Rights Fund filed the case against Exxon Mobil in the US Federal District Court of Columbia in June 2001 on behalf of 11 family members of victims of human rights abuses in Aceh allegedly committed by Exxon Mobil's security forces (members of the Indonesian military) during 2000-2001, including murder, torture, sexual assault, battery, kidnapping and false imprisonment. Following years of appeal concerning the applicability of the ATS, a US District Court ruled in 2015 that the claim could proceed because the plaintiffs' claims sufficiently 'touch and concern' the US thereby overcoming the presumption against extraterritoriality that applies to ATS cases. ${ }^{169}$

At present, this avenue of access to justice for victims remains open but the case is clearly contentious and the restriction of the ATS in the Kiobel case undermines confidence in a successful outcome. ${ }^{170}$ Furthermore, the dismissal of the FreeportMcMoRan cases for lack of an actionable case, originally filed on behalf of the Amungme people of West Papua for allegations of human rights and environmental violations by Freeport at the Grasberg mine, does not invoke much optimism for the success of similar claims in the future. ${ }^{171}$

\footnotetext{
167 Forest Peoples Programme (2013, 2016c).

168 Mongabay (2013).

169 US District Court for the District of Columbia, John Doe et al. v. Exxon Mobil Corporation et al., No. 01-1357, Memorandum Opinion (6 July 2015).

170 US Supreme Court, Kiobel v. Royal Dutch Petroleum, No. 10-1491 (17 April 2013).

171 US District Court for the District of Louisiana, Tom Beanal on behalf of himself and all others similarly situated v. Freeport-McMoRan Inc and Freeport-McMoRan Copper and Gold, Inc, Civil Action No. 96-1474, 969 F.Supp. 362 (10 April 1997); US Court of Appeals for the Fifth Circuit, Tom Beanal on behalf of himself and all others similarly situated $v$. Freeport-McMoRan Inc and Freeport-McMoRan Copper and Gold, No. 98-30235, 197 F.3d 161 (5th Cir. 29 November 1999); US Court of Appeal of Louisiana, Yosefa Alomang on behalf of himself and all others similarly situated v. Freeport-McMoRan Inc and Freeport-McMoRan Copper and Gold, No. 2000-CA-2099 (4th Cir. 20 February 2002).
} 


\section{Conclusion}

This article has explored the erosion of the public-private distinction in the provision of security as it has evolved in Indonesia, demonstrating that this has happened in a very different way to the ideologically driven outsourcing of security found in the US and UK. Despite the fact that international law is based on an outmoded view of the state, it has been possible to identify the international legal framework of obligations applicable to Indonesia, especially as regards security actors operating within specific natural resources sectors. Although there is an upward movement in Indonesia's ratification of key international human rights treaties, in contrast to its lack of active engagement with soft law instruments and processes, there is scant evidence of compliance by the government of Indonesia in terms of implementing legislation. Furthermore, there is disturbing evidence of continuing serious human rights violations by Indonesian security actors both public and private.

The article has considered Indonesia's international legal responsibility for those human rights violations, both in terms of direct liability for actions of its police and military even when acting for commercial gain, and indirect liability for failing to fulfil its due diligence obligations to control private security actors. The article also found little compliance with corporate social responsibility (CSR) norms by the corporate sector operating in Indonesia in the extractive and natural resources sectors involving agricultural commodities, even as regards the more highly developed legal regimes applicable to private security actors, let alone prevailing business and human rights standards.

The article considered whether any access to justice has been provided to remediate those violations. The evidence is that there has been very little by way remedies from either the state (in terms of admitting state liability or in terms of ensuring the prosecution of security actors committing human rights abuse while working for the corporate sector) or by the corporate actors themselves.

In a militarised and securitised state such as Indonesia, with a high density of state security, militias and private security, such actors have acted in conjunction with sector businesses to protect assets and commodities but, in so doing, they have acted in ways to increase the insecurity of the local population to the extent of regularly committing violations of core human rights. The Indonesian government's human rights commitments under international treaties and the UNGPs need to be brought into domestic laws and practices regulating the activities of state and private security actors, and should be combined with a commitment to emerging international standards in the Montreux Document, the VPSHR, and the International Code of Conduct for Private Security Providers.

In practice this means more effective prosecution of individuals with sentences to match the seriousness of the crimes, greater state regulation of security actors including an effective independent licensing system for private security actors and an acceptance of the state's responsibility for the wrongful acts of the police and military, and an increased requirement on companies to undertake human rights due diligence. In addition to increasing the recognition and implementation of state, corporate and individual legal responsibility, both the Indonesian government and 
corporate actors should provide improved access to justice and remedies for victims of human rights violations.

The direct business relationship between the two companies featured in the case studies and their respective security providers make these companies, as well as their parent companies and corporate groups, complicit in the human rights violations that have been committed, as well as being responsible for a failure to conduct human rights due diligence so as to prevent or mitigate any adverse human rights impacts that arise from the business relationship. These companies should ensure greater transparency in corporate ownership and management structures, so that the right organizations can be held accountable. Essentially, these two companies are responsible through their business relations for the violations committed on these companies' concessions, even if they did not contribute directly to them.

Although violence and intimidation towards communities appear to have been an integral part of the two companies' security practices, carried out by both public and private security providers, in limited cases only have individual personnel directly involved in violations been charged with these offences. It is recommended that the companies themselves are held responsible for their role in the violence and the human rights violations arising therefrom, either directly or indirectly. The buyers and financiers of these two companies are called upon to use their leverage, either as third-party suppliers or services providers to their supply chains, to improve the human rights policies and practices of the companies.

Open Access This article is distributed under the terms of the Creative Commons Attribution 4.0 International License (http://creativecommons.org/licenses/by/4.0/), which permits unrestricted use, distribution, and reproduction in any medium, provided you give appropriate credit to the original author(s) and the source, provide a link to the Creative Commons license, and indicate if changes were made.

\section{References}

Amnesty International (2009) Unfinished business: police accountability in Indonesia. https://www. amnesty.org/en/documents/ASA21/013/2009/en/. Accessed 5 Jul 2018

Amnesty International (2015) Amnesty International report 2014/15: the state of the world's human rights. https://www.amnesty.org/download/Documents/POL1000012015ENGLISH.PDF. Accessed 5 Jul 2018

Amnesty International (2016) The great palm oil scandal: labour abuses behind big brand names. https:// www.amnesty.org.uk/files/the_great_palm_oil_scandal_lr.pdf. Accessed 5 Jul 2018

Anghie A (2004) Imperialism, sovereignty and the making of international law. Oxford University Press, Oxford

APP (2015) Sustainability report 2015. https://www.asiapulppaper.com/system/files/app_sustainability_ report_2015.pdf. Accessed 5 Jul 2018

Bakker LGH (2017) Militias, security and citizenship in Indonesia. In: Berenschot W, Schulte H, Nordholt G, Bakker L (eds) Citizenship and democratization in Southeast Asia. Brill, Leiden, pp 125-154

Balaton-Chrimes S, Macdonald K (2016) Wilmar and palm oil grievances: the promise and pitfalls of problem solving. Non-Judicial Redress Mechanisms Report Series 8

Beittinger-Lee V (2010) (Un)Civil society and political change in Indonesia. A contested arena. Routledge, London 
Business and Human Rights Resource Centre (2009) Attacks near Freeport's Grasberg mine, West Papua, Indonesia. http://business-humanrights.org/en/documents/attacks-near-freeports-grasberg-minewest-papua-indonesia-jul-2009. Accessed 5 Jul 2018

Business and Human Rights Resource Centre (2017) Indonesia publishes national action plan on business and human rights; first to launch NAP among Asian countries. https://business-humanrights.org/ en/indonesia-to-develop-a-national-action-plan-on-business-human-rights\#c159131. Accessed 5 Jul 2018

Business and Human Rights Resource Centre (2018) Action platforms, Indonesia. https://business-human rights.org/en/indonesia-1. Accessed 5 Jul 2018

Charlesworth H (1988) The public/private distinction and the right to development in international law. Aust Yearb Int Law 12:190-204

Clarke R (2008) A matter of complicity? Exxon Mobil on trial for its role in human rights violations in Aceh. International Centre for Transitional Justice with KontraS, HRWG and Impartial, Case Study Series. https://www.ictj.org/sites/default/files/ICTJ-Indonesia-Aceh-Exxon-2008-English.pdf. Accessed 4 Jul 2018

Crawford J (2002) The International Law Commission's Articles on State Responsibility: introduction, text and commentaries. Cambridge University Press, Cambridge

Cribb R (1991) Gangsters and revolutionaries: the Jakarta People's Militia and the Indonesian Revolution 1945-1949. Asian Studies Association of Australia in association with Allen and Unwin, Sydney

Crouch H (1979) Patrimonialism and military rule in Indonesia. World Polit 31(4):571-587

Crouch H (2007) The army and politics in Indonesia. Equinox Publishing, Singapore

Dodd T (2002) Megawati and the military: too close for comfort. Austr Financ Review, 23 July 2002

Down to Earth (1999) Dayaks reoccupy traditional mines in Aurora Gold concession. Bulletin no 43. http://www.downtoearth-indonesia.org/id/node/264. Accessed 5 Jul 2018

Down to Earth (2001) Mobil Aceh rights abuse investigation. Newsletter no 43. http://www.downtoeart h-indonesia.org/story/aceh-lawsuit-accuses-exxon-mobil-complicity-abuses. Accessed 4 Jul 2018

Down to Earth (2002) Brimob shooting at Aurora mine. http://www.downtoearth-indonesia.org/story/ brimob-shooting-aurora-mine. Accessed 5 Jul 2018

Down to Earth (2004) Brutal crackdown at Newcrest's Halmahera mine leaves one dead. http://www. downtoearth-indonesia.org/story/brutal-crackdown-newcrests-halmahera-mine-leaves-one-dead. Accessed 5 Jul 2018

EarthRights International, The Centre for Environment, Human Rights and Development (2013) Assessing and improving the voluntary principles on security and human rights: lessons from the Nigerian experience. https://earthrights.org/publication/assessing-and-improving-the-voluntary-principles -on-security-human-rights/. Accessed 5 Jul 2018

Estrin S, Pelletier A (2015) Privatisation in developing countries: what are the lessons of experience? London School of Economics. https://assets.publishing.service.gov.uk/media/57a08977ed915d3 cfd000264/Topic_Guide_Privatisation_Nov.pdf. Accessed 4 Jul 2018

Forest Peoples Programme (2011) Human rights abuses and land conflicts in the PT Asiatic Persada concession in Jambi: report of an independent investigation into land disputes and forced evictions in a palm oil estate. https://www.forestpeoples.org/en/topics/palm-oil-rspo/publication/2011/human -rights-abuses-and-land-conflicts-pt-asiatic-persada-conc. Accessed 5 Jul 2018

Forest Peoples Programme (2013) Complaint regarding Wilmar Group's sale agreement of PT Asiatic Persada (Jambi, Indonesia) to non-RSPO member and non-IFC funded companies without prior consultation with Suku Anak Dalam (SAD) affected communities. http://www.forestpeoples.org/ topics/palm-oil-rspo/publication/2013/complaint-regarding-wilmar-group-s-sale-agreement-pt-asiat ic-p. Accessed 5 Jul 2018

Forest Peoples Programme (2016a) New video exposes reality of oil palm land grabs in Indonesia. http:// www.forestpeoples.org/en/responsible-finance-private-sector-palm-oil-rspo/video/2016/new-video -exposes-reality-oil-palm-land. Accessed 5 Jul 2018

Forest Peoples Programme (2016b) Yerisiam Gua people of Papua face down land grabs and intimidation by palm oil company. http://www.forestpeoples.org/topics/palm-oil-rspo/news/2016/04/yerisiamgua-people-papua-face-down-land-grabs-and-intimidation-pa. Accessed 5 Jul 2018

Forest Peoples Programme (2016c) Wilmar fails to resolve conflicts with communities in West Kalimantan and West Sumatra. http://www.forestpeoples.org/topics/palm-oil-rspo/news/2016/02/wilma r-fails-resolve-conflicts-communities-west-kalimantan-and-wes. Accessed 5 Jul 2018 
Forest Peoples Programme (2017) RSPO member ANJ accused of human rights abuses in West Papua. https://www.forestpeoples.org/en/responsible-finance-private-sector-palm-oil-rspo/news-artic le/2017/rspo-member-anj-accused-human. Accessed 5 Jul 2018

Foundation for International Human Rights Reporting Standards (2017) Indonesia launches national action plan on business and human rights. https://business-humanrights.org/sites/default/files/ documents/Indonesia\%27s\%20NAP\%20Launch.pdf. Accessed 5 Jul 2018

Global Forest Coalition (2013) Wilmar's no deforestation policy tested by latest abuses by PT Asiatic Persada. https://peopleforestsrights.wordpress.com/2013/12/20/wilmars-no-deforestation-polic y-tested-by-latest-abuses-by-pt-asiatic-persada/. Accessed 5 Jul 2018

Global Witness (2005) Paying for protection: Freeport mine and the Indonesian security forces. https:// www.globalwitness.org/en-gb/archive/paying-protection/. Accessed 4 Jul 2018)

UN Working Group on Business and Human Rights (2016) Guidance on national action plans on business and human rights. http://www.ohchr.org/Documents/Issues/Business/UNWG_NAPGuidanc e.pdf. Accessed 5 Jul 2018

Heiduk F (2014) State disintegration and power politics in post-Suharto Indonesia. Third World Q 35(2):300-315

Hendry K, Klein D (2010) The voluntary principles on security and human rights, different levels of implementation. The Fund for Peace and International Alert, Publication SVPSR1123

Human Rights Watch (2003) Without remedy. Human rights abuse and Indonesia's pulp and paper industry, vol 15, no 1 (C). https://www.hrw.org/reports/2003/indon0103/. Accessed 4 Jul 2018

Human Rights Watch (2006) Too high a price. The human rights cost of the Indonesian Military's Economic Activities, vol 18, no 5 (C). https://www.hrw.org/reports/2006/indonesia0606/indonesia0 606web.pdf. Accessed 5 Jul 2018

Human Rights Watch (2010) Unkept promise: failure to end military business activity in Indonesia. Human Rights Watch. https://www.hrw.org/sites/default/files/reports/indonesia0110webwcover.pdf. Accessed 4 Jul 2018

Human Rights Watch (2013) Indonesia: civilian courts should try abusive soldiers. https://www.hrw.org/ news/2013/04/23/indonesia-civilian-courts-should-try-abusive-soldiers. Accessed 5 Jul 2018

Human Rights Watch (2016) Indonesia: indicted general unfit for cabinet post. https://www.hrw.org/ news/2016/07/28/indonesia-indicted-general-unfit-cabinet-post. Accessed 5 Jul 2018

SOMO and Inkrispena (2017) The two hats of public security actors in Indonesia: protecting human rights or preserving business interests? Case research in the palm oil and logging sector. https:// www.somo.nl/two-hats-public-security-actors-indonesia/. Accessed 5 Jul 2018

Institute for Policy Analysis of Conflict (2014) Indigenous rights vs agrarian reform in Indonesia: a case study from Jambi. IPAC Report no 9

Institute for Policy Research and Advocacy (2017) Komnas HAM launches national action plan on business and human rights. http://elsam.or.id/2017/06/komnas-ham-lauches-national-actio n-plan-on-business-and-human-rights/. Accessed 5 Jul 2018

Institute of Ecosoc Rights, Dayak Culture Institute (Lebbaga Kebudayaan Dayak, LKD), the Commission for Justice, Peace, and Integrity of Creation (JPIC) SVD Central Kalimantan (2013) Palm oil industry and human rights: a case study on oil palm corporations in Central Kalimantan. http://www.jus.uio.no/smr/english/about/id/docs/indonesia/report-palm-oil-industry-and-human -rights-2015.pdf. Accessed 4 Jul 2018

Jones T, Newburn T (2005) Comparative criminal justice policy-making in the United States and the United Kingdom: the case of private prisons. Br J Criminol 45:58-80

Kingsbury D (2003) Power politics and the Indonesian military. Routledge Curzon, New York

Kingsbury D (2012) Two steps forward, one step back: Indonesia's arduous path of reform. ASPI Strategy, The Australian Strategic Policy Institute Limited, Canberra

Leith D (2003) The politics of power: Freeport in Suharto's Indonesia. University of Hawaii Press, Honolulu

Liss C (2014) Security sector reform in Southeast Asia: the role of private security providers. In: Heiduk F (ed) Security sector reform in Southeast Asia: from policy to practice, vol 7. Palgrave Macmillan, London

London Mining Network (2013) 'Leave us and leave our land' indigenous community tells Bumi. http://londonminingnetwork.org/2013/06/leave-us-and-leave-our-land-indigenous-communitytells-bumi/. Accessed 5 Jul 2018 
Marks S, Azizi F (2010) Responsibility for violations of human rights obligations: international mechanisms. In: Crawford J, Pellet A, Olleson S (eds) The law of international responsibility. Oxford University Press, Oxford, pp 725-738

Mill JS (1859) On liberty. Penguin, London, p 1974

Mongabay (2013) Palm oil deal undermines efforts to resolve 25-year conflict in Sumatra. https:// news.mongabay.com/2013/10/palm-oil-deal-undermines-efforts-to-resolve-25-year-conflict-insumatra/. Accessed 5 Jul 2018

Nani A (2015) Are Indonesian soldiers professional enough? The Jakarta Post, 5 October 2015. http:// www.thejakartapost.com/news/2015/10/05/are-indonesian-soldiers-professional-enough.html. Accessed 4 Jul 2018

Nozick R (1974) Anarchy, state and utopia. Basil Blackwell, Oxford

Rainforest Rescue (2014) Land grabbing for biofuels gets lethal. https://www.rainforest-rescue.org/ petitions/943/land-grabbing-for-biofuels-gets-lethal. Accessed 5 Jul 2018

Rainforest Rescue Petition (2014) Indonesia: another senseless killing for palm oil. https://www.rainf orest-rescue.org/petitions/961/indonesia-another-senseless-killing-for-palm-oil. Accessed 5 Jul 2018

Reza BI (2015) Happy birthday TNI, bring military reform back on track. The Jakarta Post, 5 October 2015. http://www.thejakartapost.com/news/2015/10/05/happy-birthday-tni-bring-military-refor m-back-track.html. Accessed 5 Jul 2018

Robinson R (1986) Indonesia: the rise of capital. Allen and Unwin, Sydney

Robinson R, Wilson I, Meliala A (2008) The rise and fall of political gangsters in Indonesian democracy. Policy Brief, Murdoch University Research Centre, Perth

Ruggie JG (2013) Just business: multinational corporations and human rights. W.W. Norton and Company, New York

Sciascia A (2013) Monitoring the border: Indonesian port security and the role of private actors. Contemp Southeast Asia J Int Strat Aff 35(2):163-187

Setiawan K (2016) The politics of compromise. Inside Indonesia. http://www.insideindonesia.org/thepolitics-of-compromise-2. Accessed 9 Jan 2018

Special Representative of the Secretary-General on the issue of human rights and transnational corporations and other business enterprises (2011) Guiding Principles for the implementation of the United Nations 'Protect, respect and remedy' framework, UN Doc A/HRC/17/31 (21 March 2011), endorsed by the Human Rights Council, Res 17/4 (16 June 2011)

Stanger A (2009) One nation under contract: the outsourcing of American power and the future of foreign policy. Yale University Press, New Haven

Steinebach S (2013) 'Today we occupy the plantation-tomorrow Jakarta': indigeneity, land and oil palm plantations in Jambi. In: Hauser-Schäublin B (ed) Adat and indigeneity in Indonesia. Universistätsverlag Göttingen, Göttingen, pp 63-79

Sukma R, Prasetyono E (2003) Security sector reform in Indonesia: the military and the police. Netherlands Institute of International Relations 'Clingendael', Working Paper no 9

US Department of State, Bureau of Democracy, Human Rights and Labor (2014) Country reports on human rights practices for 2014, Indonesia, Executive Summary. http://www.state.gov/j/drl/rls/hrrpt /humanrightsreport/index.htm\#wrapper. Accessed 5 Jul 2018

Vidal J (2008) Shattered illusions. The Guardian, 19 March 2008

Voluntary Principles Initiative (2015) Summary of implementation efforts during 2015. http://www.volun taryprinciples.org/wp-content/uploads/2016/06/VPs_-_Summary_Annual_Report_of_Implementa tion_Efforts_in_2015.pdf. Accessed 5 Jul 2018

Walker N (2003) Late sovereignty in the European Union. In: Walker N (ed) Sovereignty in transition: essays in European Law. Hart, Oxford, pp 3-32

White ND (2012) Due diligence obligations of conduct: developing a responsibility regime for PMSCs. Crim Justice Ethics 31:233-261

Yunanto S (2006) Parliament and private business in the security sector. Dialogue Cooper 3:45-60 


\section{Affiliations}

Nigel D. White ${ }^{1} \cdot$ Mary E. Footer $^{1} \cdot$ Kerry Senior $^{2} \cdot$ Mark van Dorp $^{3}$. Vincent Kiezebrink ${ }^{3}$. Y. Wasi Gede Puraka ${ }^{4}$ Ayudya Fajri Anzas ${ }^{4}$

Mary E. Footer

mary.footer@nottingham.ac.uk

Kerry Senior

kerry.senior@nottingham.ac.uk

Mark van Dorp

markvandorp@mac.com

Vincent Kiezebrink

v.kiezebrink@somo.nl

Y. Wasi Gede Puraka

ywasigede@inkrispena.org

Ayudya Fajri Anzas

ayuanzas@gmail.com

1 University of Nottingham, Nottingham, UK

2 Nottingham International Law and Security Centre, University of Nottingham, Nottingham, UK

3 SOMO, Amsterdam, The Netherlands

4 Inkrispena, Jakarta, Indonesia 